\title{
Validity and reliability of the Perceived Efficacy and Goal Setting System (PEGS) for Brazilian children
}

\author{
Carina Iracema Bigonha Ruggio ${ }^{a}$, Cheryl Missiuna ${ }^{b}$, Samara de Araújo Costa ${ }^{a}$ (D), \\ Clarice Ribeiro Soares Araújo ${ }^{c}$, Lívia de Castro Magalháes ${ }^{d}$
}

\author{
${ }^{a}$ Universidade Federal de Minas Gerais - UFMG, Belo Horizonte, MG, Brasil. \\ ${ }^{b}$ McMaster University and Investigator at CanChild, Centre for Childhood Disability Research, Ontario, Canada. \\ 'Departamento de Terapia Ocupacional, Universidade Federal da Paraíba - UFPB, João Pessoa, PB, Brasil. \\ dDepartamento de Terapia Ocupacional, Universidade Federal de Minas Gerais - UFMG, Belo Horizonte, MG, Brasil.
}

\begin{abstract}
Introduction: The engagement in client-centered practice requires instrumentation that allows the participation of the child and family in the definition of treatment goals. Objective: The aim of the present study was to pilot a translated version of the Perceived Efficacy and Goal Setting System (PEGS) and determine its validity and reliability for clinical use with Brazilian children. Method: Eighty children six to nine years old (40 public school children and 40 private school children), as well as their caregivers and teachers, completed the PEGS. Results: The children understood the pictures and interview procedures. Caregivers and teachers reported no difficulties in understanding the questionnaires. Gender, age, and type of school had no significant influence over the children's scores. Cultural influence on the response to two items was identified but could be resolved with extra explanation. Stability of the goals was supported and the children, caregivers, and teachers appear to share views regarding the overall abilities of the children. Conclusion: The PEGS has potential for clinical use with Brazilian children, but clinicians should be aware that some items require further instructions. The usefulness of the PEGS as a tool to promote client-centered practice among Brazilian occupational therapists should be investigated.
\end{abstract}

Keywords: Reproducibility of Results, Self-assessment, Goals, Children.

\section{Validade e confiabilidade do Perceived Efficacy and Goal Setting System (PEGS) para crianças brasileiras}

Resumo: Introdução: $\mathrm{O}$ envolvimento da prática centrada no cliente requer instrumentação adequada que permita as participações da criança e da família na definição das metas de tratamento. Objetivo: O objetivo do presente trabalho foi realizar estudo piloto da versão traduzida Perceived Efficacy and Goal Setting System (PEGS), assim como determinar a validade e a confiabilidade deste instrumento para uso clínico com crianças brasileiras. Método: Oitenta crianças de seis a nove anos de idade ( 40 crianças de escolas públicas e 40 crianças de escolas particulares), bem como seus cuidadores e professores, completaram o PEGS. Resultados: As crianças compreenderam tanto as figuras quanto os procedimentos da entrevista. Cuidadores e professores não relataram dificuldades na compreensão dos questionários. Gênero, idade e tipo de escola não tiveram influência significativa nas pontuações das crianças. Porém, as respostas à dois itens do estudo piloto, parecem ter sido influenciadas pela cultura, ; mas pôde ser resolvida com explicação extra. A estabilidade das metas foi mantida, e as crianças, cuidadores e professores pareceram compartilhar pontos de vista em comum com relação às habilidades gerais das crianças. Conclusão: O PEGS tem potencial para uso clínico com crianças brasileiras; no entanto, os profissionais devem estar conscientes de que alguns itens requerem instruções adicionais. A utilidade do PEGS, como ferramenta para promover a prática centrada no cliente entre terapeutas ocupacionais brasileiros, deve ser investigada.

Palavras-chave: Reprodutibilidade dos Testes, Autoavaliação, Metas, Crianças.

Corresponding author: Samara de Araújo Costa, Universidade Federal de Minas Gerais, Departamento de Terapia Ocupacional, Av. Antônio Carlos, 6627, CEP 31270-901, Belo Horizonte, MG, Brasil, e-mail: samaracosta.to@gmail.com

Received on Apr. 8, 2018; Revision on Aug. 22, 2018; Accepted on Aug. 31, 2018.

This is an Open Access article distributed under the terms of the Creative Commons Attribution License, which permits unrestricted use, distribution, and reproduction in any medium, provided the original work is properly cited 


\section{Introduction}

Due to its philosophy of respect and consideration to parents and children, family-centered care has become the recommended model in child healthcare practices (KUHLTHAU et al., 2011). This philosophy of care is associated with improved health and well-being, improved family functioning, increased parental participation in children's intervention program, higher satisfaction, more efficiency, better family-team communication and better overall service provision for children with special health care needs (ROSENBAUM et al., 1998; KUHLTHAU et al., 2011; BREWER; POLLOCK; WRIGHT, 2014; KING; CHIARELLO, 2014). Family centered care is embedded within the concept of client-centeredness, which is central to occupational therapy (PHOENIX; VANDERKAAY, 2015).

A client centered approach implies on active participation of the client and/or family in all steps of treatment, including the determination of therapy goals, which requires, among other things, listening to the client and relying on resources to give the child and his/her family a voice in the intervention process (MISSIUNA et al., 2006). Collaborative goal setting with clients/families has been considered a key piece in client/family centered approach (BREWER; POLLOCK; WRIGHT, 2014). Its benefits include clarity of focus and shared understanding of the intervention goals, which facilitate communication and enhances team work; parents as well, feel more competent and collaborate more with the team (BREWER; POLLOCK; WRIGHT, 2014).

The use of an explicit goal setting process has been recommended as a strategy to improve the quality of care and as a means to advance our knowledge concerning best practices in engaging in collaborative goal setting within a client/family centered approach (BREWER; POLLOCK; WRIGHT, 2014). Family-centered principles inspire Brazilian mother-child health care policies (BRASIL, 2013), however, the usual challenges to implement a client-centered approach (PHOENIX; VANDERKAAY, 2015) are enhanced by economic restraints. Instruments to support therapists in embracing a family centered approach, such as the Canadian Occupational Performance Measure, have been translated to Brazilian Portuguese (LAW et al., 2009), however pediatric therapists need more specific resources to give the child and his/her family a voice in the intervention process.

Realizing that children were capable to self-evaluate their motor skills and that this ability could be used in the identification of treatment goals, Missiuna,
Pollock and Law (2004) created the Perceived Efficacy and Goal Setting System (PEGS), based on a previous questionnaire, the All About Me (MISSIUNA, 1998). Using PEGS, children are able to identify tasks he/she can perform with ease or difficulty and choose relevant goals for therapy. Along with the protocol for interviewing the child, the PEGS includes questionnaires for caregivers and teachers, which allows comparing and adjusting treatment goals.

The PEGS was created to enable children with motor disability to report self-perceptions regarding their skill in performing activities of daily living and select treatment goals in accordance with their own perspective (MISSIUNA; POLLOCK; LAW, 2004). PEGS fits well into the current notions of client-centered practice (TOWNSEND, 2002; AOTA, 2014), in which joint identification and determination of treatment goals with the client is an integral part of the intervention process. Engaging the child and parents in the goal determination process appears to lead to better results in therapy (MISSIUNA et al., 2006; VROLAND-NORDSTRAND et al., 2016). Research has shown that both children and parents are able to set goals for intervention (MISSIUNA et al., 2006; MISSIUNA; POLLOCK, 2000; DUNFORD et al., 2005; COSTA; BRAUCHLE; KENNEDY-BEHR, 2016) and that goals set by children can be trusted and may be prioritized to improve their involvement in therapy (VROLAND-NORDSTRAND et al., 2016).

The PEGS has been translated in different languages (COSTA, 2004; ENGEL-YEGER; HANNA-KASIS, 2010; VROLAND-NORDSTRAND; KRUMLINDE-SUNDHOLM, 2012a) and our interest in translating into Portuguese is due to the absence of instruments to support Brazilian occupational therapists working with children to engage in client-centered practice. The use of PEGS will help Brazilian occupational therapists to focus on functional goals of interest to the child, family and teachers, thereby contributing toward a much needed transition to a client-centered model. As the interview is based on pictures, it is important to determine whether Brazilian children understand the figures and interview procedures before employing the PEGS in clinical practice.

The aims of the present study were to determine whether Brazilian children, students from public and private schools of different ages, understand the PEGS pictures and are capable of appraising their skill level. Internal consistency of the scales was examined and whether there were differences between the child's self-perception and that of 
caregivers and teachers. Stability of the goals chosen by the children was also investigated.

\section{Method}

\subsection{Participants}

Eighty children between six and nine years of age with typical development participated in the present study - 40 from public schools and 40 from private schools in the metropolitan region of the city of Belo Horizonte, Brazil. Each group was subdivided according to age. Each subgroup contained ten children aged either six, seven, eight or nine years, with equal representation of boys and girls. Children with specific neurological or genetic disorders (i.e., cerebral palsy, autism, mental retardation, hearing and/or seeing impairment, continual use of anticonvulsants) and those with risk factors for motor problems (i.e., prematurity or low birth weight, orthopedic problems, prolonged illness in the three months prior to the test, history of school problems with need for tutoring or specialized therapy) were excluded from the study.

In order to examine the impact of socioeconomic level on the children's self-perception of skill, children from middle and upper-middle classes in the private schools and children from lower and upper-lower classes in the public schools were recruited.

\subsection{Instrumentation}

The Perceived Efficacy and Goal Setting System (PEGS) (MISSIUNA; POLLOCK; LAW, 2004) consists of a protocol for interviewing children, a questionnaire for caregivers and another questionnaire for teachers. In the interview with the child, 27 pairs of test cards are used, with illustrations of children performing motor activities involving self-care, school work and playing. Each pair is composed of one card that shows a child performing the activity with ease (more skillful) and another showing a child having difficulty performing the same activity (less skillful). The cards display a small statement describing the activity. The occupational therapist reads the statement and instructs the child to choose the picture that resembles him/her more. After choosing one of the cards, the child indicates if his/her performance is a little or a lot similar to the chosen picture, this procedure results in a four point scale, varying from $1=a$ lot similar to the better performance to $4=$ a lot similar to the poor performance. Three of the cards illustrate activities performed by children with physical handicaps and are only to be administered to children who use wheelchairs or crutches. One pair of cards is blank and is used to encourage the child to suggest a different activity from those depicted on the other cards. The child's responses are registered on a specific form, which has room to list up to four activities in which the child has interest in learning. The questionnaires for caregivers and teachers have items that correspond to the cards presented to the children. Caregivers and teachers are asked to identify whether the child has difficulty performing any of the activities, scoring each activity with the same four point scale of the children's questionnaire. The teachers' questionnaire has four fewer items, which were omitted for referring to activities not normally observed at school (cutting food, playing videogames, riding a bicycle and buttoning).

Internal consistency of the scale of the protocol for children has been found to be $\alpha=0.795$ (Cronbach's) (MISSIUNA; POLLOCK, 2000; MISSIUNA; POLLOCK; LAW, 2004), test-retest reliability (based on the AAM) ranged from 0.76 to 0.79 and there is evidence of stability in children's choices of goals (MISSIUNA; POLLOCK; LAW, 2004). These results suggest the PEGS is a reliable method for facilitating a child's determination of goals and that the particular goals are stable.

To exclude children with possible motor coordination problems (as envisaged in the recruitment criteria), we used the Brazilian version of the Developmental Coordination Disorder Questionnaire (DCDQ) (WILSON et al., 2000), which is a parents' questionnaire designed to screen developmental coordination disorders. The DCDQ-Brazil and has shown good test-retest reliability $(0.97)$ and validity for Brazilian children (PRADO; MAGALHÁES; WILSON, 2009). Since there are as yet no Brazilian norms for the DCDQ-Brazil, we used the Canadian cutoff points, as average performance values are similar in both countries (PRADO; MAGALHÃES; WILSON, 2009; PRADO, 2007).

\subsection{Procedures}

Authorization for the PEGS translation was solicited from the Psychological Corporation ${ }^{\circledR}$, which published the test. Cross-cultural translation was conducted according to international recommendations (COSTER; MANCINI, 2015), encompassing four stages: initial double translations, synthesis of translations, back-translation, and final translated version (BIGONHA, 2008). For the experimental phase of the study, data was collected in public and private schools. At the schools that agreed to 
participate, contact with the teachers was made to explain the objectives and procedures of the study and, with the teachers as intermediaries, envelopes were sent to the caregivers, containing a term of consent, the PEGS questionnaire for caregivers, the DCDQ-Brazil and a letter asking for the return of the contents of the envelope (whether filled out or not) within three days. The teachers of those children who fulfilled the inclusion criteria and whose caregivers returned the envelopes with the questionnaires filled out received the PEGS questionnaire for teachers, with a five-day return deadline.

Children were interviewed at school at a time established by the teacher and in a quiet room. Data were collected by the first author and an undergraduate occupational therapy research student, both trained in the procedures described in the PEGS manual. To determine stability of the goals established, 16 children from the overall sample (four from each age group) were selected by chance and performed the protocol a second time, within a two weeks interval. Caregivers and teachers were not expected to answer the questionnaires again, as the objective was to determine stability of the children's goals. The project received approval from the Research Ethics Committee - COEP/UFMG (process no. 0305/06).

\subsection{Data analysis}

Descriptive statistics were used to characterize the participants. Stability of the goals was determined by counting the coinciding goals on both administrations of the instrument, followed by conversion to percentage values, according to the procedures described in the PEGS manual (MISSIUNA; POLLOCK; LAW, 2004). Cronbach's $\alpha$ coefficient was used to determine internal consistency of the three scales.

To determine whether there were differences in the scores between the different respondents, conversion to percentage scores was performed, as the questionnaire for teachers have a lesser number of items. As normality of the data was not confirmed (i.e., Shapiro-Wilk test), Friedman's non-parametric test was used to determine whether there were differences between the child's self-perception and the perception of the caregiver and teacher. The Mann-Whitney and Kruskal-Wallis tests were used to determine the relationship between the percentage scores of the children and the variables gender, type of school and age. The weighted Kappa coefficient was used to determine agreement between the child, caregiver and teacher regarding performance on the individual PEGS items. For further analysis, the original four point scale of the PEGS' items were dichotomized as competent/not competent, and agreement between the child, caregiver and teacher was again analyzed using Cohen's kappa coefficient. The criteria used to interpret the Kapa's coefficients were: below 0.40 indicates poor agreement, 0.41 to 0.74 indicates moderate agreement and for values above 0.75 the agreement is good to excellent (STREINER; NORMAN, 2008).

\section{Results}

Individual interviews with the children lasted 20 to 30 minutes, the six-year-olds took longer, as it was necessary to give more explanations. The children understood most of the pictures, but it was necessary to give greater explanation regarding Item 6 (Making things/Putting things together), giving examples of activities carried out in art classes. On Item 16 (playing ball games), some children pointed out that they had never played with a baseball bat, which appears in the picture. On both items, with minor explanation, all children were able to score the item. On Item 28, which solicits information on extra activities that are not included on the test, few children were able to give examples of other activities.

Some children from the public schools reported having never had the opportunity to perform the activities on Item 4 (playing videogames), Item 12 (using a computer) or Item 14 (riding a bicycle). The children from private schools commented on the exaggerated manner in which the less skillful performance is depicted on Item 17 (writing), Item 19 (organized desk) and Item 20 (painting/drawing). Two children from private and 11 from public schools did not establish any goals, they all scored high (91-96) in the PEGS interview for children.

Teachers from both types of school solicited assistance from the physical education teacher to fill out the questionnaire and no teacher expressed any doubts regarding the instructions or filling out the items. However, only 35 (43.75\%) teachers answered Part 2 of the PEGS questionnaire for teachers adequately, which requires to point items in which the child's performance could improve. Most of the goals established referred to the items related to attention/concentration. Among the 40 questionnaires responded by public school teachers, only 15 (37.5\%) presented goals, whereas $50 \%$ of the questionnaires responded by private school teachers presented goals. No caregiver expressed any doubts regarding the instructions of the PEGS questionnaire for caregivers or filling out the items. Twenty-six (65\%) caregivers 
with children in public schools presented goals for their children, whereas 35 (87.5\%) caregivers with children in private schools presented goals. Table 1 displays the most cited goals at both types of school by the children, teachers and caregivers.

Among the 16 children who underwent the PEGS interview a second time, three $(18.75 \%)$ selected one coinciding goal; nine $(56.25 \%)$ selected two coinciding goals; three (18.75\%) selected three coinciding goals; and one (6.25\%) selected four coinciding goals. Thus, all the children who were interviewed twice with the PEGS selected at least one coinciding goal. Moreover, one child selected exactly the same goals on both occasions. Cronbach's $\alpha$ coefficient values for the PEGS-Brazil scales were $0.808,0.703$ and 0.881 for the child, caregiver and teacher questionnaires, respectively.

Table 2 displays the total PEGS raw score and total percentage scores, according to gender, age and type of school. The Friedman test revealed no significant differences between the total percentage scores on the three scales $\left(\mathrm{X}_{\mathrm{r}}^{2}=1.994, \mathrm{p}=0.369\right)$, meaning that the median percentage total was similar for children, caregivers and teachers. The weighted Kappa coefficient (Table 3) indicated that agreement between child-caregiver, child-teacher and caregiver-teacher scores was low for most of the individual items, but the positive values demonstrate agreement above what would be expected by chance. In the child-caregiver comparison, there was agreement below that which would be expected by chance for the "organizing page numbers" (for which the children reported being more skillful) and "running" (for which the caregivers reported the child being more skillful). In the child-teacher comparison, there were differences in perspective for "organizing page numbers" and "dressing" (children reported being more skillful at both tasks). In the caregiver-teacher comparison, caregivers considered the children more skillful at "playing on the playground", "using a zipper" and "coloring/painting" than teachers. When agreement was analyzed using dichotomous ratings, the Kapa coefficient values showed increments, ranging from -0.068 to 0.385 for the child-caregiver, from -0.64 to 0.431 for the child-teacher and from -0.077 to 0.672 for the caregiver-teacher ratings, however, no item reached the range of good to excellent agreement for any paired comparison.

The Mann-Whitney test revealed no significant differences in the total percentage scores of the children regarding gender $(\mathrm{Z}=-0.728, \mathrm{p}=0.470)$ or school $(\mathrm{Z}=-1.952, \mathrm{p}=0.051)$. The Kruskal-Wallis

$\underline{\text { Table 1. Most cited goals by children, caregivers and teachers at each type of school. }}$

\begin{tabular}{|c|c|c|c|}
\hline & Goals & Private school & Public school \\
\hline \multirow[t]{9}{*}{ Child } & & $\mathrm{n}=38 *$ & $\mathrm{n}=29 *$ \\
\hline & Cutting food & 11 times & 10 times \\
\hline & Playing videogames & 10 times & - \\
\hline & Riding a bicycle & 10 times & - \\
\hline & Making cutouts & 8 times & 5 times \\
\hline & Finishing homework & 7 times & 5 times \\
\hline & Catching a ball & - & 8 times \\
\hline & Writing & - & 4 times \\
\hline & Drawing & - & 4 times \\
\hline \multirow[t]{6}{*}{ Caregiver } & & $\mathrm{n}=35^{*}$ & $\mathrm{n}=15^{*}$ \\
\hline & Better handwriting & 10 times & 11 times \\
\hline & Riding a bicycle & 9 times & - \\
\hline & Cutting food & - & 7 times \\
\hline & Tying shoes & 5 times & - \\
\hline & Drawing & - & 5 times \\
\hline \multirow[t]{8}{*}{ Professor } & & $\mathrm{n}=20^{*}$ & $\mathrm{n}=15^{*}$ \\
\hline & Better handwriting & 10 times & 6 times \\
\hline & Using scissors & 4 times & - \\
\hline & Desk more organized & 3 times & 3 times \\
\hline & Painting/coloring & 3 times & - \\
\hline & Tying shoes & 3 times & - \\
\hline & Drawing & - & 2 times \\
\hline & Finishing homework & - & 2 times \\
\hline
\end{tabular}

*Number of children, caregivers and teachers who established goals. 
Table 2. Median/mean values of raw PEGS scores and total percentage score for gender, age and type of school.

\begin{tabular}{|c|c|c|c|c|c|c|c|}
\hline & $\mathbf{N}$ & $\begin{array}{l}\text { Child } \\
\text { Mean }\end{array}$ & Median & $\begin{array}{c}\text { Caregiver } \\
\text { Mean }\end{array}$ & Median & $\begin{array}{c}\text { Teacher } \\
\text { Mean }\end{array}$ & Median \\
\hline \multicolumn{8}{|l|}{ Gender } \\
\hline Female & 40 & 86.30 & 89.00 & 88.10 & 90.00 & 70.15 & 72.00 \\
\hline Male & 40 & 87.08 & 90.00 & 86.18 & 87.00 & 70.15 & 72.00 \\
\hline \multicolumn{8}{|l|}{ Age } \\
\hline 6 & 20 & 86.95 & 89.00 & 87.15 & 87.50 & 68.10 & 70.50 \\
\hline 7 & 20 & 87.35 & 88.50 & 86.25 & 87.50 & 68.90 & 69.00 \\
\hline 8 & 20 & 86.90 & 89.00 & 85.50 & 87.00 & 70.50 & 74.50 \\
\hline 9 & 20 & 85.55 & 87.50 & 89.65 & 91.50 & 73.10 & 73.50 \\
\hline \multicolumn{8}{|l|}{ School } \\
\hline Private & 40 & 85.05 & 88.00 & 87.13 & 88.00 & 72.18 & 74.50 \\
\hline Public & 40 & 88.33 & 90.00 & 87.15 & 88.00 & 68.13 & 71.00 \\
\hline Total & 80 & $\begin{array}{c}86.69 \\
( \pm 8.07)\end{array}$ & 89.00 & $\begin{array}{c}87.14 \\
( \pm 6.82)\end{array}$ & 88.00 & $\begin{array}{c}70.15 \\
( \pm 8.64)\end{array}$ & 72.00 \\
\hline $\begin{array}{l}\text { Total Percentage } \\
\text { Score }\end{array}$ & 80 & $\begin{array}{c}90.39 \% \\
( \pm 8.33 \%)\end{array}$ & $92.71 \%$ & $\begin{array}{c}91.04 \% \\
( \pm 6.93 \%)\end{array}$ & $91.67 \%$ & $\begin{array}{c}89.92 \% \\
( \pm 11.06 \%)\end{array}$ & $92.50 \%$ \\
\hline
\end{tabular}

Table 3. Mean score, weighted Kappa and percentage of agreement for each PEGS' item.

\begin{tabular}{lccccccccc}
\hline \multicolumn{1}{c}{ Item do PEGS } & Child & Caregiver & Teacher & $\begin{array}{c}\text { Child- } \\
\text { Caregiver }\end{array}$ & \multicolumn{2}{c}{$\begin{array}{c}\text { Child- } \\
\text { Teacher }\end{array}$} & \multicolumn{2}{c}{$\begin{array}{c}\text { Caregiver- } \\
\text { Teacher }\end{array}$} \\
\hline Catching a ball & 3.26 & 3.78 & 3.64 & 0.096 & $58 \%$ & 0.305 & $64 \%$ & 0.278 & $73 \%$ \\
Cutting food & 3.26 & 2.87 & - & 0.280 & $43 \%$ & - & - & - & - \\
Sports & 3.59 & 3.69 & 3.59 & 0.378 & $70 \%$ & 0.194 & $60 \%$ & 0.361 & $71 \%$ \\
Playing videogames & 3.25 & 3.70 & - & 0.194 & $63 \%$ & - & - & - & - \\
Finishing homework on time & 3.54 & 3.41 & 3.41 & 0.314 & $63 \%$ & 0.409 & $68 \%$ & 0.412 & $63 \%$ \\
Making things with the hands & 3.63 & 3.85 & 3.69 & 0.089 & $76 \%$ & 0.056 & $64 \%$ & 0.027 & $73 \%$ \\
Participating in games and & 3.81 & 3.56 & 3.64 & 0.251 & $66 \%$ & 0.120 & $73 \%$ & 0.229 & $68 \%$ \\
sports & & & & & & & & & \\
Tying shoes & 3.73 & 3.45 & 3.54 & 0.183 & $75 \%$ & 0.127 & $72 \%$ & 0.322 & $68 \%$ \\
Making cutouts & 3.43 & 3.63 & 3.55 & 0.105 & $54 \%$ & 0.327 & $65 \%$ & 0.206 & $63 \%$ \\
Playing in the playground & 3.85 & 3.80 & 3.69 & 0.137 & $83 \%$ & 0.075 & $78 \%$ & $\mathbf{- 0 . 0 1 0 *}$ & $74 \%$ \\
Buttoning & 3.71 & 3.83 & - & 0.082 & $78 \%$ & - & - & - & - \\
Using the computer & 3.71 & 3.67 & 3.63 & 0.379 & $76 \%$ & -0.045 & $63 \%$ & 0.196 & $69 \%$ \\
Organizing page numbers & 3.76 & 3.69 & 3.56 & $\mathbf{- 0 . 0 0 8 *}$ & $71 \%$ & $\mathbf{- 0 . 0 0 1 *}$ & $66 \%$ & 0.357 & $67 \%$ \\
Riding a bicycle & 3.48 & 3.47 & - & 0.558 & $73 \%$ & - & - & - & - \\
Dressing & 3.79 & 3.88 & 3.78 & $*$ & $78 \%$ & $\mathbf{- 0 . 0 1 3 *}$ & $72 \%$ & 0.017 & $78 \%$ \\
Ball games & 3.56 & 3.73 & 3.58 & 0.351 & $73 \%$ & 0.135 & $64 \%$ & 0.157 & $68 \%$ \\
Writing & 3.59 & 3.41 & 3.31 & 0.371 & $63 \%$ & 0.381 & $65 \%$ & 0.425 & $61 \%$ \\
Using a zipper & 3.73 & 3.88 & 3.80 & 0.021 & $75 \%$ & 0.000 & $74 \%$ & $\mathbf{- 0 . 0 0 3 *}$ & $83 \%$ \\
More organized desk & 3.83 & 3.47 & 3.50 & 0.008 & $59 \%$ & 0.012 & $69 \%$ & 0.345 & $62 \%$ \\
Coloring/painting & 3.70 & 3.81 & 3.50 & 0.037 & $74 \%$ & 0.038 & $65 \%$ & $\mathbf{- 0 . 0 0 6 *}$ & $65 \%$ \\
Drawing & 3.81 & 3.66 & 3.54 & 0.347 & $78 \%$ & 0.288 & $73 \%$ & 0.376 & $70 \%$ \\
Jumping rope & 3.50 & 3.61 & 3.63 & 0.369 & $70 \%$ & 0.059 & $58 \%$ & 0.223 & $66 \%$ \\
Kicking a ball & 3.55 & 3.62 & 3.59 & 0.226 & $68 \%$ & 0.079 & $61 \%$ & 0.205 & $67 \%$ \\
Running & 3.73 & 3.95 & 3.74 & $\mathbf{- 0 . 0 0 1 *}$ & $83 \%$ & 0.017 & $69 \%$ & Error* & $78 \%$ \\
\hline Sign
\end{tabular}

*Significant agreement ( $\mathrm{p}>.05)$.**Impossible to calculate index due to complete agreement of score.

test revealed no significant difference with regard to age $\left(\mathrm{X}^{2}=0.877, \mathrm{p}=0.831\right)$.

\section{Discussion}

All children understood the PEGS format and were capable of responding to the interview and choose tasks in which they would like to improve their performance. Considering the participants were children with typical development, choosing treatment goals was not the major concern, but rather identifying motor activities in which they believed they had greater difficulty. The fact, however, that no children had reported school or motor difficulties may have reduced the interest of caregivers and teachers in establishing performance goals. 
Although Missiuna, Pollock and Law (2004) state that the PEGS' items were drafted with the aim of including activities that were not influenced by culture, socioeconomic issues in Brazil may have influenced the self-evaluation of performance in certain activities, as some public school children reported not having played videogames, used a computer or ridden a bicycle (Table 1). Socioeconomic issues were not reported in studies of both Austrian-German and Swedish versions of PEGS, probably because there are many commonalities between European countries and Canada (COSTA, 2004; VROLAND-NORDSTRAND; KRUMLINDE-SUNDHOLM, 2012a). In the Brazilian context, two items required extra explanation, children were in doubt about the picture in item 6, and games with bats are not very popular in Brazil. With explanation, however, children were able to score these items, apparently without compromising the end result of the interview and goal definition process.

The duration of the interview with Brazilian children (approximately 30 minutes) was similar to what is reported in the PEGS' manual (MISSIUNA; POLLOCK; LAW, 2004), but shorter than the 40-60 minutes reported by Costa (2004). The shorter time reported here probably is explained by the fact that children had no developmental issues; therefore, goal definition was much shorter or absent. In the present study, younger children required more orientation and had a tendency to tell stories about the illustrations, which increased the length of some interviews. The stories told by the children prolonged the interviews, however, they were rich and offered clues regarding to what the child attributed his/her difficulty in specific tasks. Even occupational therapists who consider PEGS time consuming, acknowledge its therapeutic value in assessing and planning intervention in a collaborative way (COSTA, 2004).

Concerning the quality of the scales, the value for internal consistency on the child scale $(\alpha=0.808)$ surpassed that reported in the PEGS manual $(\alpha=0.795)$ (MISSIUNA; POLLOCK; LAW, 2004). Data from the questionnaires for caregivers $(\alpha=0.703)$ and teachers $(\alpha=0.881)$ have not yet been reported in the literature, and confirm the satisfactory internal consistency of the PEGS questionnaires. Although internal consistency for the caregiver's questionnaire was lower than the recommended value of 0.80 (STREINER; NORMAN, 2008), as the items are the same on the three scales and no individual item was identified that contributed toward the reduction in this coefficient, this may be a sample related variation, and it is recommended these values be monitored in future studies.

Another positive point was that $100 \%$ of the children interviewed established at least one coinciding goal on the retest and one child repeated exactly the same goals. This result is quite satisfactory, as one would not expect total agreement, considering that the choice of goals is highly influenced by new learning experiences (MISSIUNA; POLLOCK; LAW, 2004), which may change on a daily basis in children with typical development. The children assessed by Missiuna et al. (2006) and Vroland-Nordstrand and Krumlinde-Sundholm (2012b) demonstrated greater stability in goals, which may be attributed to the presence of motor disability, that could accentuate difficulties and guide the selection of specific goals. Further investigations should verify if there are differences in the choice of goals by children with and without motor disability and if differences are defined based on persistent difficulties with certain tasks or by momentary interests.

No significant differences were found between the perceptions of caregivers, teachers and children based on the total scores on the PEGS, which supports the notion that children are capable of self-evaluation (STURGESS; RODGER; OZANNE, 2002; VROLAND-NORDSTRAND et al., 2016; COSTA; BRAUCHLE; KENNEDY-BEHR, 2016). The Kappa index (Table 3), however, indicated low agreement between children, parents and teachers for most individual items. When considering dichotomous ratings for the items, the Kappa coefficient increased, but still did not reach values that indicate good to excellent agreement, which was also seen in other studies (VROLAND-NORDSTRAND; KRUMLINDE-SUNDHOLM, 2012b; COSTA; LINDENTHAL, 2015). This finding suggests it is important to listen and negotiate between different views in order to define treatment goals.

The present study has limitations; the separation of the groups into public and private schools is questionable, as this does not necessarily define differentiated social groups, which may have limited the possibility of identifying significant differences in the PEGS scores. However, this is a practical division used on a number tests validated for the Brazilian children, which report separate norms for children from public and private schools (ANGELINI et al., 1999; WECHSLER, 1996). The inclusion of children with developmental coordination disorder or other developmental disabilities would have contributed toward advancing the validation of the instrument. However, as the PEGS is illustrated, we considered important to verify the comprehension of typically 
developing children before administering the instrument to a clinical sample; we pondered it would be more difficult to assert the comprehension of children with motor or cognitive problems, as they generally have difficulty expressing themselves. Thus, it was possible to verify the quality of the translation and prepare the instrument for clinical use. On the other hand, we believe that when PEGS is administered to children with disabilities, the caregivers, teachers and children themselves may show greater involvement in the goal setting section of the instrument.

\section{Conclusion}

The children were capable of understanding the PEGS protocol and the instrument appears useful in determining treatment goals for Brazilian children, but therapists must be careful administering the items as some may require added explanation for comprehension. Caregivers and teachers were capable of answering the questionnaires and were able to collaborate in the identification of strong and weak points as well as in the definition of desired goals to improve performance. The translation is ready for research use, but modifications of the pictures of the two items that raised more doubts during the children's interviews should be considered in futures editions of the PEGS. The PEGS-Brazil should be used in further validity studies, including children of different ages and with different levels of motor disability, to investigate its feasibility and usefulness as a tool to support Brazilian occupational therapists client-centered practice with children.

\section{Acknowledgements}

This study was partially supported by grants from the Fundação de Amparo à Pesquisa do Estado de Minas Gerais (FAPEMIG) and the Conselho Nacional de Desenvolvimento Científico e Tecnológico (CNPq). Our special thanks to Patrícia Rodrigues da Costa, for her assistance in data collection, and to the children, parents and teachers who kindly participated in the study.

\section{REFERENCES}

AMERICAN OCCUPATIONAL THERAPY ASSOCIATION - AOTA. Occupational therapy practice framework: domain and process. The American Journal of Occupational Therapy, Bethesda, v. 68, p. 1-48, 2014. Supplement 1. http://dx.doi.org/10.5014/ajot.2014.682006.
ANGELINI, A. L. et al. Manual matrizes progressiva coloridas de raven: escala especial. São Paulo: CETEPP, 1999.

BIGONHA, C. Adaptação transcultural do Perceived Efficacy and Goal Setting System - PEGS para crianças brasileiras. 2008. 98 f. Dissertação (Mestrado em Ciências da Reabilitação) - Universidade Federal de Minas Gerais, Belo Horizonte, 2008.

BRASIL. Atenção humanizada ao recém nascido de baixo peso: Método Canguru. Brasília: Ministério da Saúde, 2013. Disponível em: <http://bvs.saude.gov.br/bvs/publicacoes/ atencao_humanizada_recem_nascido_canguru.pdf $>$. Acesso em: 7 abr. 2018.

BREWER, K.; POLLOCK, N.; WRIGHT, F. V. Addressing the challenges of collaborative goal setting with children and their families. Physical \& Occupational Therapy in Pediatrics, London, v. 34, n. 2, p. 138-152, 2014. http:// dx.doi.org/10.3109/01942638.2013.794187.

COSTA, U. M. Translation and cross-cultural adaptation of the Perceived Efficacy and Goal Setting System (PEGS): results from the first Austrian-German PEGS version exploring meaningful activities for children. OTJR: Occupation, Participation and Health, Thorofare, v. 34, n. 3, p. 119-130, 2004. http://dx.doi.org/10.3928/1539449220140325-02.

COSTA, U. M.; BRAUCHLE, G.; KENNEDY-BEHR, A. Collaborative goal setting with and for children as part of therapeutic intervention. Disability and Rehabilitation, London, v. 39, n. 16, p. 1589-1600, 2016. http://dx.doi. org/10.1080/09638288.2016.1202334. PMid:27385635.

COSTA, U. M.; LINDENTHAL, M. J. Perceived competences in everyday activities: children's self-report and parents' and teachers' report using the first AustrianGerman Perceived Efficacy and Goal Setting System (AGPEGS) version. International Journal of Health Professions, Technikumstr, v. 2, n. 1, p. 16-30, 2015. http://dx.doi. org/10.1515/ijhp-2015-0001.

COSTER, W. J.; MANCINI, M. C. Recommendations for translation and cross-cultural adaptation of instruments for occupational therapy research and practice. Revista de Terapia Ocupacional da Universidade de São Paulo, São Paulo, v. 26, n. 1, p. 50-57, 2015. http://dx.doi.org/10.11606/ issn.2238-6149.v26i1p50-57.

DUNFORD, C. et al. Children's perceptions of the impact of developmental coordination disorder on activities of daily living. British Journal of Occupational Therapy, London, v. 68, n. 5, p. 207-214, 2005. http://dx.doi. org/10.1177/030802260506800504.

ENGEL-YEGER, B.; HANNA-KASIS, A. The relationship between developmental co-ordination disorders, child's perceived self-efficacy and preference to participate in daily activities. Child: Care, Health and Development, Oxford, v. 36, n. 5, p. 670-677, 2010. http://dx.doi. org/10.1111/j.1365-2214.2010.01073.x. PMid:20412146.

KING, G.; CHIARELLO, L. Family-centered care for children with cerebral palsy: conceptual and practical 
considerations to advance care and practice. Journal of Child Neurology, Littleton, v. 29, n. 8, p. 1046-1054, 2014. http://dx.doi.org/10.1177/0883073814533009. PMid:24810084.

KUHLTHAU, K. A. et al. Evidence for family-centered care for children with special health care needs: a systematic review. Academic Pediatrics, New York, v. 11, n. 2, p. 136143, 2011. http://dx.doi.org/10.1016/j.acap.2010.12.014.

LAW, M. et al. Medida Canadense de Desempenho Ocupacional (COPM). Belo Horizonte: Editora Universidade Federal de Minas Gerais, 2009.

MISSIUNA, C. Development of "All About Me", a scale that measures children's perceived motor competence. OTJR: Occupation, Participation and Health, Thorofare, v. 18 , n. 2, p. 85-108, 1998.

MISSIUNA, C. et al. Examination of the perceived efficacy and goal setting system (PEGS) with children with disabilities, their parents, and teachers. The American Journal of Occupational Therapy, Bethesda, v. 60, n. 2, p. 204-214, 2006. http://dx.doi.org/10.5014/ajot.60.2.204.

MISSIUNA, C.; POLLOCK, N. Perceived efficacy and goal setting in young children. Canadian Journal of Occupational Therapy, Thousand Oaks, v. 67, n. 3, p. 101-109, 2000. http://dx.doi.org/10.1177/000841740 006700303 .

MISSIUNA, C.; POLLOCK, N.; LAW, M. Perceived Efficacy and Goal Setting System (PEGS). San Antonio: Psychological Corporation, 2004.

PHOENIX, M.; VANDERKAAY, S. Client-centred occupational therapy with children: a critical perspective. Scandinavian Journal of Occupational Therapy, London, v. 22, n. 4, p. 318-321, 2015. http://dx.doi.org/10.3109 /11038128.2015.1011690.

PRADO, M. S. S. Tradução e adaptação cultural do Developmental Coordination Disorder Questionnaire (DCDQ). 2007. 81 f. Dissertação (Mestrado em Ciências da Reabilitação) - Universidade Federal de Minas Gerais, Belo Horizonte, 2007.

PRADO, M. S. S.; MAGALHÃES, L. C.; WILSON, B. N. Cross-cultural adaptation of the developmental coordination disorder questionnaire for Brazilian children. Brazilian Journal of Physical Therapy, São Carlos, v. 13, n. 3, p. 236-243, 2009. http://dx.doi.org/10.1590/S141335552009005000024 .
ROSENBAUM, P. et al. Family-centred service: a conceptual framework and research review. Physical o Occupational Therapy in Pediatrics, Philadelphia, v. 18, n. 1, p. 1-20, 1998.

STREINER, D. L.; NORMAN, G. R. Health measurement scales: a practical guide to their development and use. Oxford: Oxford University Press, 2008. http://dx.doi. org/10.1093/acprof:oso/9780199231881.001.0001.

STURGESS, J.; RODGER, S.; OZANNE, A. A review of the use of the self-report assessment with young children. British Journal of Occupational Therapy, London, v. 65, n. 3, p. 108-116, 2002. http://dx.doi. org/10.1177/030802260206500302.

TOWNSEND, E. Enabling occupation: an occupational therapy perspective. Canadian Association Of Occupational Therapists - CAOT Publications: Ottawa, 2002.

VROLAND-NORDSTRAND, K. et al. Can children identify and achieve goals for intervention? A randomized trial comparing two goal-setting approaches. Developmental Medicine and Child Neurology, Oxford, v. 58, n. 6, p. 589-596, 2016. http://dx.doi.org/10.1111/dmcn.12925. PMid:26374194.

VROLAND-NORDSTRAND, K.; KRUMLINDESUNDHOLM, L. The Perceived Efficacy and Goal Setting System (PEGS), part I: translation and cross-cultural adaptation to a Swedish context. Scandinavian Journal of Occupational Therapy, London, v. 19, n. 6, p. 497-505, 2012a. http://dx.doi.org/10.3109/11038128.2012.684 221. PMid:22571377.

VROLAND-NORDSTRAND, K.; KRUMLINDESUNDHOLM, L. The Perceived Efficacy and Goal Setting System (PEGS), part II: evaluation of test-retest reliability and differences between child and parental reports in the Swedish version. Scandinavian Journal of Occupational Therapy, London, v. 19, n. 6, p. 506-514, 2012b. http://dx.doi.org/10.3109/11038128.2012.685 759. PMid:22571409.

WECHSLER, S. M. O desenho da figura humana: avaliação do desenvolvimento cognitivo infantile - Manual para crianças brasileiras. Cascavel: Ed. Psy, 1996.

WILSON, B. N. et al. Reliability and validity of a parent questionnaire on childhood motor skills. The American Journal of Occupational Therapy, Bethesda, v. 54, n. 5, p. 484-493, 2000. http://dx.doi.org/10.5014/ajot.54.5.484. PMid: 11006808 .

\section{Author's Contributions}

Carina Iracema Bigonha Ruggio, Cheryl Missiuna e Lívia de Castro Magalhães participaram de todas as fases trabalho, desde a concepção e delineamento do estudo até a escrita final e revisão. As demais autoras contribuíram para a escrita do trabalho, organização de fontes e/ou análises, redação do texto e revisão crítica final. Todas as autoras aprovaram a versão final do texto.

\section{Funding Source}

FAPEMIG e CNPq 